Article

\title{
Impact of Ethyl Methane Sulphonate Mutagenesis in Artemisia vulgaris L. under $\mathrm{NaCl}$ Stress
}

\author{
Sudheeran Pradeep Kumar ${ }^{1, *}$ and B.D. Ranjitha Kumari ${ }^{2}$ \\ 1 Department of Postharvest Science of Fresh Produce, Agricultural Research Organization (ARO), The Volcani \\ Center, P.O. Box 15159, HaMaccabim Road 68, Rishon Lezion 7505101, Israel \\ 2 Department of Botany, Bharathidasan University, Tiruchirappalli 620024, India; \\ Ranjithakumari2004@yahoo.com \\ * Correspondence: pradeepkumar2k@gmail.com; Tel.: +91-994-5867-169
}

Citation: Kumar, S.P.; Kumari, B.R. Impact of Ethyl Methane Sulphonate Mutagenesis in Artemisia vulgaris L. under $\mathrm{NaCl}$ Stress. BioTech 2021, 10, 18. https://doi.org/10.3390/ biotech10030018

Academic Editor: Atsushi Fukushima

Received: 26 June 2021

Accepted: 17 August 2021

Published: 21 August 2021

Publisher's Note: MDPI stays neutral with regard to jurisdictional claims in published maps and institutional affiliations.

Copyright: (c) 2021 by the authors. Licensee MDPI, Basel, Switzerland. This article is an open access article distributed under the terms and conditions of the Creative Commons Attribution (CC BY) license (https:// creativecommons.org/licenses/by/ $4.0 /)$.

\begin{abstract}
The present investigation aimed to obtain salt-tolerant Artemisia vulgaris L. to develop a constant form through in vitro mutagenesis with ethyl methane sulphonate (EMS) as the chemical mutagen. $\mathrm{NaCl}$ tolerance was evaluated by the ability of the callus to maintain its growth under different concentrations, ranges from $(0 \mathrm{mM}$ to $500 \mathrm{mM})$. However, $\mathrm{NaCl}$ salinity concentration at (500 $\mathrm{mM})$ did not show any development of callus, slight shrinking, and brown discoloration taking place over a week. Thus, all the biochemical and antioxidant assays were limited to $(0-400 \mathrm{mM}) \mathrm{NaCl}$. On the other hand, selected calluses were treated with 0.5\% EMS for 30,60, and 90 min and further subcultured on basal media fortified with different concentrations of 0-400 mM NaCl separately. Thus, the callus was treated for $60 \mathrm{~min}$ and was found to induce the mutation on the callus. The maximum salt-tolerant callus from $400 \mathrm{mM} \mathrm{NaCl}$ was regenerated in MS medium fortified with suitable hormones. Biochemical parameters such as chlorophyll, carotenoids, starch, amino acids, and phenol contents decreased under $\mathrm{NaCl}$ stress, whereas sugar and proline increased. Peroxidase (POD) and superoxide dismutase (SOD) activities peaked at $200 \mathrm{mM} \mathrm{NaCl}$, whereas catalase (CAT) was maximum at $100 \mathrm{mM} \mathrm{NaCl}$. Enhanced tolerance of $0.5 \%$ the EMS-treated callus, attributed to the increased biochemical and antioxidant activity over the control and $\mathrm{NaCl}$ stress. As a result, the mutants were more tolerant of salinity than the control plants.
\end{abstract}

Keywords: antioxidants; Artemisia vulgaris L.; ethyl methane sulphonate (EMS); mutagenesis; salt-tolerance; superoxide dismutase (SOD)

\section{Introduction}

A. vulgaris L. (mugwort) is a medicinally useful traditional plant and is widely being used for the healing of diabetes. Its extract is used for epilepsy and various combinations for psychoneurosis, irritability, depression, sleeplessness, and anxiety stress, among other things [1]. The plant is also a highly efficient antidote to insect or pest poison. In addition, some of the antibacterial potentials and phytochemical screenings were evaluated for the medicinal plant such as Vitex negundo L. against plant pathogens that were previously reported [2]. The in vitro regeneration of the high artemisinin-producing somaclonal variation against $(\mathrm{NaCl})$ salt-tolerance and the improvement of sequence-characterized amplified region (SCAR) markers in 'Artemisia annua L.' were reported by [3].

Salt stress is a major environmental limitation that has a global impact on plant yield and distribution. Salinity $(\mathrm{NaCl})$ inhibits plant growth by altering homeostasis in water status and ionic distribution and causing oxidative stress. Due to a rise in salt concentration, around $20 \%$ of the world's framed surfaces are considered non-fertile [4]. The semiarid and arid zones are especially prone to environmental concerns [5]. Ion toxicity, osmotic pressure, mineral shortages, and a mix of physiological and biochemical abnormalities are all common symptoms of salt stress [6]. The plant cell adaptation and variation towards high level salinity involve osmotic change and the compartmentalization of toxic ions, 
whereas an increasing body of evidence suggests that high salinity also stimulates the formation of oxidative stress and reactive oxygen species (ROS) [7].

Plants have developed several defense mechanisms, and one of them is an antioxidant system and capability of surviving harmful oxidation in situations that favour the formation of oxidative stress, such as salt stress. Plant cells have developed a sophisticated antioxidant system that comprises both low molecular-mass antioxidants andreactive oxygen species (ROS)-scavenging enzymes, together with peroxidase (POD), superoxide dismutase (SOD), and catalase (CAT) [8]. Furthermore, plants continuously produce reactive oxygen species (ROS) as a by-product of many physiological, metabolic pathways, such as photo-respiration, photosynthesis, and $\mathrm{CO}_{2}$ absorption. Whether ROS behave as harmful, protective, or signaling components is determined by the delicate balance between ROS production and scavenging mechanisms to adjust the correct spot and timing [9]. The most vital enzymatic antioxidant is superoxide dismutase (EC 1.15.1.1); it catalyzes the dismutation of the $\mathrm{O}_{2}$ into $\mathrm{H}_{2} \mathrm{O}_{2}$, which is then deactivated to water by peroxidase (EC 1.11.1.7) and catalase (EC 1.11.1.6).

In crop development, mutation initiation has emerged as a novel strategy in crop improvement to supplement the technical limitations of conventional breeding in improving cultivars for specific attributes. According to previous accounts, more than 2500 enhanced mutant varieties have been released for marketable production [10]. Mutagenesis has become popular in recent decades due to its ease of use, low cost, applicability to all plant species, and ability to be used on a small or large scale. The frequency of produced mutations can be matched by adjusting the mutagen dose, and saturation can be easily reached [11]. In vitro culture is a good technique for the selection of salt-tolerant mutants, as it is carried out under controlled conditions with limited time [12]. Furthermore, unlike the entire plant, many numerous lines can be screened for the required feature at the same time. Salt-tolerant cell lines and plants have been derived from plant tissue culture techniques in a variety of species, including rice, wheat $[13,14]$.

Plants that are tolerant to biotic or abiotic stress have a variety of resistance mechanisms, such as osmoregulation, ion homeostasis, and antioxidant and hormonal systems, serving plants to stay alive and develop prior to their reproductive stages [15]. To accomplish salt tolerance, plant cells evolve numerous biochemical and physiological traits to achieve salt tolerance. The in vitro tissue culture system is effective for assessing tolerance to environmental stresses due to the stress conditions. In vitro tissue culture is a useful technique for studying the physiological and biochemical systems that function at the cellular level in response to stress [16,17].

Cell line collection and subsequent plant regeneration have been employed extensively in the production of salt-tolerant plants $[18,19]$. These findings were new for the ethyl methane sulphonate (EMS) or other chemical mutagens used on callus and whole plant regeneration of A. vulgaris for salt-tolerance. The goal of this work is to use the EMS in vitro approach and plant regeneration to create a salt-tolerant mutant.

\section{Materials and Methods}

\subsection{Seed Germination and Explant Establishment}

The seeds of A. vulgaris were obtained from the company Johnny's Selected Seeds, located at Winslow, Maine, USA. Seeds were surface sterilized and germinated on MS media containing $10 \%$ filter sterilized coconut water. A total of 95 percent of the seeds germinated after 5-7 days of dark exposure at $23^{\circ} \mathrm{C}$. Fully developed seedlings were observed within 30 days of being switched to photoperiodic settings conditions $(16 / 8 \mathrm{~h} \mathrm{light/dark)}$ at $25 \pm 1{ }^{\circ} \mathrm{C}$, performed accordingly by [20]. The explants for this investigation were taken from nodal segment explants were excised from 35 -day-old in vitro grown seedlings.

\subsection{Callus Initiation}

Explants were carefully dissected (nodal) from 35-day-old in vitro seedlings and cultured in basal nutrient medium Murashige and Skoog (MS), supplemented with $B_{5}$ 
vitamins 3percent $(w / v)$ sucrose, $4.52 \mu \mathrm{M}$ 2,4-Dichlorophenoxy acetic acid (2-4, D), and $2.65 \mu \mathrm{M} \alpha$-Naphthalene acetic acid (NAA) (Himedia, Mumbai, India), for callus induction [21,22]. The $\mathrm{pH}$ of the medium was adjusted to 5.7 (supplemented with a growth regulator) with $1 \mathrm{~N} \mathrm{NaOH}$ or $1 \mathrm{~N} \mathrm{HCl}$ (Himedia, Mumbai, India), before gelling with 0.8 percent agar (Himedia, Mumbai, India), and autoclaved at $121^{\circ} \mathrm{C}$ for $15 \mathrm{~min}$ at $15 \mathrm{lbs}$ pressure. The explants were placed on the culture medium horizontally. All the cultures were incubated at $25 \pm 1{ }^{\circ} \mathrm{C}$ for optimum growth and development. Two subcultures were performed at 10-day time intervals.

\subsection{Assessment of $\mathrm{NaCl}$ Tolerant}

After 25 days, the viable callus was chopped into small pieces of 5-6 mm size and further inoculated on a callus initiation medium supplemented with varied $\mathrm{NaCl}$ concentrations $(0,100,200,300,400$ and $500 \mathrm{mM})$. Subcultures of these culture mediums were performed three times at 10-day intervals. The survival rate of callus growth was assessed in all $\mathrm{NaCl}$ concentrations ranging from (0 to $500 \mathrm{mM}$ ). High salinity at $500 \mathrm{mM} \mathrm{NaCl}$ was found to be fatal for the callus development and at $400 \mathrm{mM} \mathrm{NaCl}$, the callus can survive for more than 30 days. Therefore, $400 \mathrm{mM} \mathrm{NaCl}$ was chosen as the proper concentration for this present investigation.

\subsection{Ethyl Methane Sulphonate (EMS) Treatment}

After 25 days of callus induction, it was cut into small pieces, weighed, and treated with $0.5 \%$ EMS solution (made in sterilized distilled water and membrane filtered) for $30 \mathrm{~min}, 60 \mathrm{~min}$, and $90 \mathrm{~min}$, respectively, and inoculated on MS Basal media containing varied concentrations of $\mathrm{NaCl}(0$ to $400 \mathrm{mM}), \mathrm{B}_{5}$ vitamins, 3percent $(w / v)$ sucrose, $5.42 \mu \mathrm{M}$ of $2(2-4, D)$ and $2.65 \mu \mathrm{M}$ of (NAA). Three subcultures were carried out at 10-day intervals between them. Finally, calluses were collected for further regeneration with a $400 \mathrm{mM}$ $\mathrm{NaCl}$ concentration.

\subsection{Shoot Induction and Elongation}

For shoot induction and regeneration, EMS-treated calluses were transferred to a basal medium containing $B_{5}$ vitamins, supplemented with 3percent $(w / v)$ sucrose, $4.44 \mu \mathrm{M}$ of $\mathrm{N}^{6}$-benzyladenine (BA), and $2.78 \mu \mathrm{M}$ of Thidiazuron (TDZ) (Sigma-Aldrich, Bangalore, India) fortified with the selection pressure of $400 \mathrm{mM} \mathrm{NaCl}$ [21]. After that, multiple shoots were then transferred to the shoot elongation medium containing MS basal salts, $\mathrm{B}_{5}$ vitamins, 3percent $(w / v)$ sucrose, and $1.44 \mu \mathrm{M}$ of Gibberellic acid $\left(\mathrm{GA}_{3}\right)$ (Sigma-Aldrich, Bangalore, India).

\subsection{Rooting and Acclimatization of Plantlets}

After 2-3 weeks, elongated shoots were removed from the elongation medium and transferred to MS media supplemented with various concentrations of Indole-3-acetic acid (IAA), (Himedia, Mumbai, India), (2.85, 5.70, 8.55, and $11.40 \mu \mathrm{M})$. Plantlets with well-developed roots were removed from the rooting media and rinsed the adventitious roots-gently under running tap water to remove the adhering material; plantlets were then transferred to artificial cups (10 cm diameter) containing with autoclaved garden soil, farmyard soil, and sand (2:1:1) for hardening. Plantlets were kept in a culture environment maintained at $\left(25 \pm 1{ }^{\circ} \mathrm{C}\right)$ conditions. Each plantlet was sprayed with distilled water every two days for 3 weeks, followed by tap water for 2 weeks and transferred to conventional laboratory conditions.

\subsection{Biochemical Analysis}

\subsubsection{Evaluation of Chlorophyll and Carotenoid}

Chlorophylls $(\mathrm{a}+\mathrm{b})$ and carotenoid contents were determined by extracting pigments in $80 \%$ acetone (Himedia, Mumbai, India), and calculated as $\mathrm{mg} / \mathrm{g}$ FW as described by [18]. 


\subsubsection{Evaluation of Total Soluble \& Reducing Sugars, and Starch}

The anthrone-sulphuric acid method was used to quantify total soluble sugars and starch using $0.2 \%$ anthrone (Sigma-Aldrich, Bangalore, India) in concentrated $\mathrm{H}_{2} \mathrm{SO}_{4}$ as a reagent [23]. Spectrophotometric data were collected at $630 \mathrm{~nm}$ against a reagent blank. With $0-100 \mathrm{mg}$ of glucose, a standard curve was plotted against various concentrations levels. The starch concentration was calculated by multiplying the resulting value by 0.9 for the conversion of glucose value to the starch [24]. The arsenomolybdate reagent (SigmaAldrich, Bangalore, India) was used to estimate reducing sugars using the alkaline copper technique, and absorbance was measured at $510 \mathrm{~nm}$. A standard curve was established against graded pure glucose $(0-50 \mathrm{mg})$ to assess sugar content reduction.

\subsubsection{Evaluation of Total Free Amino Acids, Proline, and Total Phenols}

The total free amino acids were extracted from callus samples with $70 \%$ ethanol (Himedia, Mumbai, India), and calculated using ninhydrin reagent (Sigma-Aldrich, Bangalore, India) as described in [25]. A standard curve against glycine was used to compute the sum of total free amino acids $(0-100 \mathrm{mg})$. The free proline content was extracted from callus using 3\% sulphosalicylic acid using L-proline (Sigma-Aldrich, Bangalore, India)) as a reference solution and estimated according to [26]. Total phenols were evaluated by using $10 \%$ Folin phenol reagent and standard $\mathrm{NaHCO}_{3}$ (Himedia, Mumbai, India) according to [27]. The absorbance was measured using catechol as the standard in a spectrophotometer at $660 \mathrm{~nm}$.

\subsubsection{Antioxidant Enzyme Assay}

In vitro, one gram of fresh callus from the control, $\mathrm{NaCl}$ stress, and EMS treatments were homogenised in $2 \mathrm{~mL}$ of $50 \mathrm{mM}$ potassium phosphate buffer ( $\mathrm{pH}$ 7.5) (Himedia, Mumbai, India) containing $2 \mathrm{mM}$ EDTA and were centrifuged at $15,000 \mathrm{~g}$ for $20 \mathrm{~min}$ at $4{ }^{\circ} \mathrm{C}$. Ammonium sulfate precipitation was used to concentrate the protein content in the supernatant, which was then filtered through Whatman No.1 filter sheets. A spectrophotometer (Mettler-Toledo, Mumbai, India) was used to determine the activity of chosen enzymes. The protein concentration at each fraction was determined by the method [28].

\subsubsection{Activity of Catalase}

Catalase (EC 1.11.1.6) activity was determined using a modified version of the method described in [29]. The test was performed with $2.6 \mathrm{~mL}$ of $50 \mathrm{mM}$ potassium phosphate buffer ( $\mathrm{pH} 7.0$ ), $0.4 \mathrm{~mL}$ of $15 \mathrm{mM} \mathrm{H}_{2} \mathrm{O}_{2}$, (Himedia, Mumbai, India) and $0.04 \mathrm{~mL}$ of enzyme extract. The decrease in $\mathrm{H}_{2} \mathrm{O}_{2}$ absorbance at $240 \mathrm{~nm}$ coincided with the breakdown of $\mathrm{H}_{2} \mathrm{O}_{2}$. The enzyme activity was measured in units $\mathrm{mg}^{-1}$ protein $\left(\mathrm{U}=1 \mathrm{mM}\right.$ of $\mathrm{H}_{2} \mathrm{O}_{2}$ reduction $\mathrm{min}^{-1} \mathrm{mg}^{-1}$ protein).

\subsubsection{Activity of Peroxidase}

The amount of soluble peroxidase (EC 1.11.1.7) activity was assayed by the method described by [30]. Two $\mathrm{mL}$ of $0.1 \mathrm{M}$ phosphate buffer ( $\mathrm{pH}$ 6.8), $1 \mathrm{~mL}$ of $0.01 \mathrm{M}$ pyrogallol, Sigma-Aldrich, Bangalore, India) $1 \mathrm{~mL}$ of $0.005 \mathrm{M} \mathrm{H}_{2} \mathrm{O}_{2}$, and $0.5 \mathrm{~mL}$ of enzyme extract made up the POX assay combination. The amount of solution was incubated for $5 \mathrm{~min}$ at $25{ }^{\circ} \mathrm{C}$, after which the reaction was stopped by adding $1 \mathrm{~mL}$ of $2.5 \mathrm{~N} \mathrm{H}_{2} \mathrm{SO}_{4}$. The total amount of purpurogallin produced was calculated by measuring the absorbance at $420 \mathrm{~nm}$ against a blank prepared by adding the extract after the addition of $2.5 \mathrm{~N} \mathrm{H}_{2} \mathrm{SO}_{4}$ at zero time. The activity was measured in the unit's $\mathrm{mg}^{-1}$ protein. One unit $(\mathrm{U})$ is defined as the change in the absorbance by $0.1 \mathrm{~min}^{-1} \mathrm{mg}^{-1}$ protein.

\subsubsection{Superoxide Dismutase Activity}

The amount of superoxide dismutase (EC 1.15.1.1) activity was determined according to method described by [31]. In $3 \mathrm{mLof}(0.05 \mathrm{M})$ sodium phosphate buffer ( $\mathrm{pH} 7.8)$, the reaction mixture of $1.17 \times 10^{-6} \mathrm{M}$ riboflavin, $0.1 \mathrm{M}$ methionine, $2 \times 10^{-5} \mathrm{M} \mathrm{KCN}$, and 
$5.6 \times 10^{-5} \mathrm{M}$ Nitroblue tetrazolium salt (NBT) (Sigma-Aldrich, Bangalore, India) were dissolved. A total of $3 \mathrm{~mL}$ of reaction medium was added to $1 \mathrm{~mL}$ of enzyme extract. The reaction mixtures were illuminated in glass test tubes by two sets of Philips direct $40 \mathrm{~W}$ fluorescent lights in a single row. Elucidation was started at $30^{\circ} \mathrm{C}$ for $1 \mathrm{~h}$ to initiate the reaction. Blank samples were kept in the dark for $30 \mathrm{~min}$ at the same time. The reduction was calculated based on changes in NBT. In the spectrophotometer, absorbance was calculated at $560 \mathrm{~nm}$ against the blank. One enzyme unit was defined as the volume of the enzyme extract corresponding to $50 \%$ inhibition of the process. The superoxide dismutase (SOD) activity was measured in units of $\mathrm{mg}^{-1}$ protein $\mathrm{min}^{-1}$.

\subsubsection{Statistical Analysis}

In each subsequent test, the data values are given as the mean \pm standard deviation (SD) for six plants. Duncan's Multiple Range Test (DMRT) with a 0.05 percent significant criterion was to perform post hoc testing for intergroup comparisons. To assess the results, the SPSS software package for Windows (version 11.5; SPSS Inc., Chicago, IL, USA) was used to perform a one-way analysis of variance (ANOVA).

\section{Results}

\subsection{NaCl's Effect on Callus Growth and Plant Regeneration}

Different concentrations of $\mathrm{NaCl}(0,100,200,300,400$, and $500 \mathrm{mM})$ were used for assessing $\mathrm{NaCl}$ tolerance in callus formation in A. vulgaris. Calluses could tolerate maximum salinity $(\mathrm{NaCl})$ stress up to $400 \mathrm{mM}$ and could sustain for more than 30 days (Figure 1a-e), whereas for salinity at the $500 \mathrm{mM}$ concentration, calluses began browning, and the death of the tissues takes place after a week (Figure 1f). Thus, all the experiments were conducted with calluses treated with $\mathrm{NaCl}$ concentrations between 0 and $400 \mathrm{mM}$. After 3 weeks of incubation, explants cultured on MS medium regenerated the callus and regeneration of the whole plant of A. vulgaris from control callus ( $0 \mathrm{mM} \mathrm{NaCl}$ stress) (Figure 2a,b).

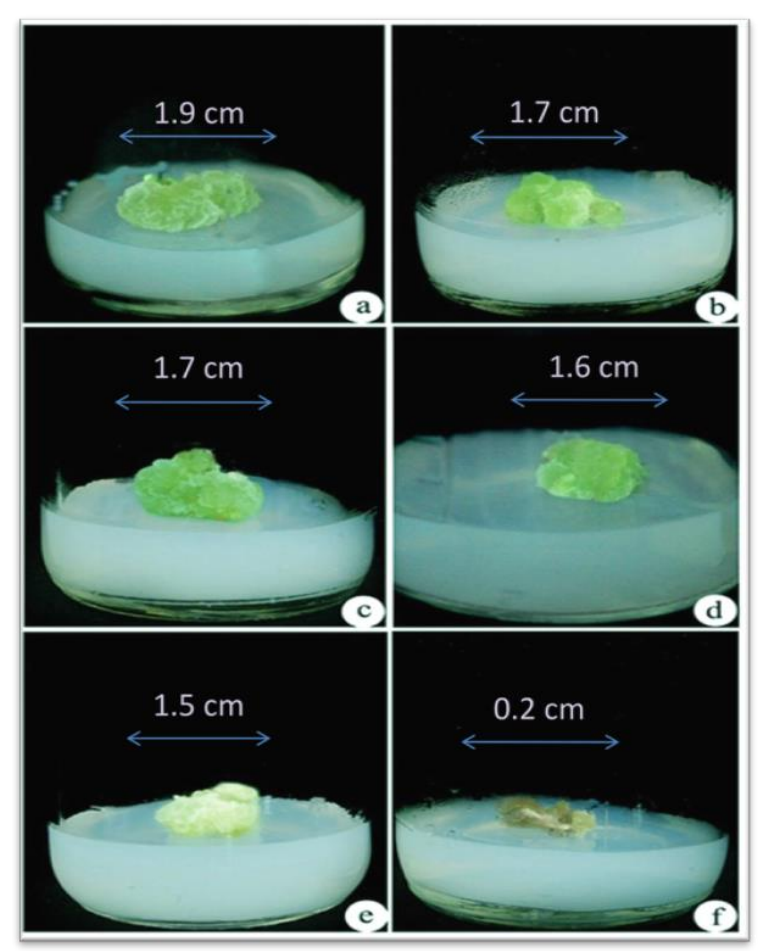

Figure 1. Assessment of $\mathrm{NaCl}$ tolerance in callus of A. vulgaris. (a) Control callus culture from $(0 \mathrm{mM} \mathrm{NaCl}),(\mathbf{b})$ callus cultured on $(100 \mathrm{mM} \mathrm{NaCl}),(\mathbf{c})$ callus cultured on $(200 \mathrm{mM} \mathrm{NaCl}),(\mathbf{d})$ callus cultured on $(300 \mathrm{mM} \mathrm{NaCl}),(\mathbf{e})$ callus cultured on $(400 \mathrm{mM} \mathrm{NaCl})$ showed its growth reduction and discoloration, (f) dead calluses at $(500 \mathrm{mM} \mathrm{NaCl})$ concentration after 30 days. 


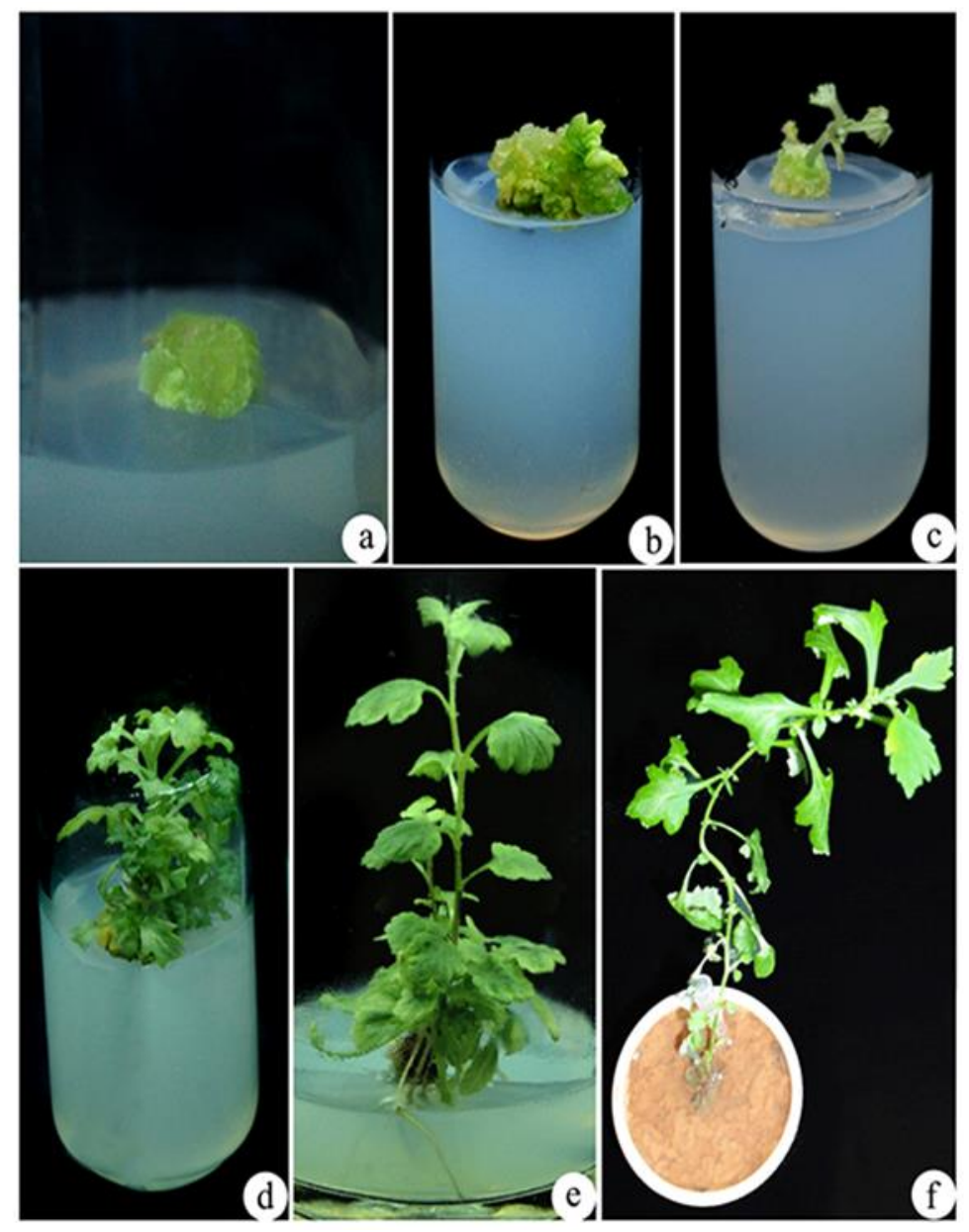

Figure 2. In vitro regeneration of $A$. vulgaris from control callus ( $0 \mathrm{mM} \mathrm{NaCl}$ stress). (a) Regenerated callus from nodal explants, $(\mathbf{b}, \mathbf{c})$ shoot induction from the callus, (d)multiple shoots proliferation, (e) elongated shoot with roots, (f) hardened plant in the cup.

\subsection{Ethyl Methane Sulphonate (EMS) Treatment on Callus}

To assess the high salinity $(\mathrm{NaCl})$ stress, almost all callus growth was reduced after being treated with $0.5 \%$ of EMS for $30 \mathrm{~min}$ and $90 \mathrm{~min}$ was inhibited. In our study, it was noticed that $30 \mathrm{~min}$ exposure of $0.5 \%$ EMS treatment may be too short for causing mutagenesis in improving salt tolerance. However, the treatment of EMS for $90 \mathrm{~min}$ was found to be considerably more hazardous and had a detrimental influence on callus proliferation, whereas EMS treatment for $60 \mathrm{~min}$ resulted in a good survival rate of the callus. It suggests that the treatment of $0.5 \%$ EMS for $60 \mathrm{~min}$ is optimum for the induced mutation in the callus (Figure 3). 


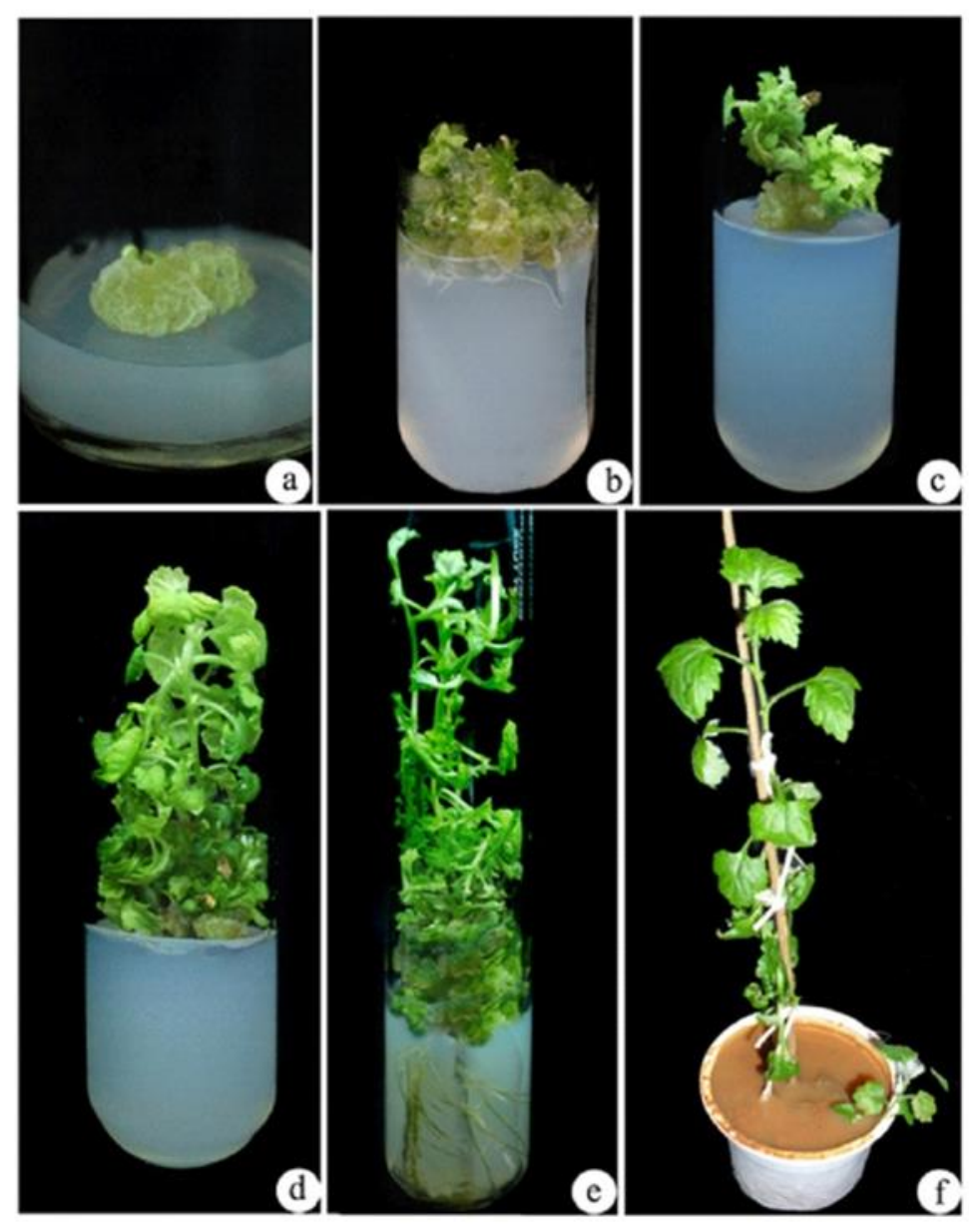

Figure 3. Influence of ethyl methane sulphonate (EMS) $0.5 \%$ on the growth of mutants from callus of A. vulgaris on $\mathrm{NaCl}$ stressed media. (a) Regenerated callus, $(\mathbf{b}, \mathbf{c})$ shoot induction from callus, (d) multiple shoots induction and elongation from callus, (e) multiple shoot induction with roots, (f) hardened plant in a cup.

\subsection{Shoot Elongation and Rooting}

After 4 weeks of $A$. vulgaris callus treatment with $400 \mathrm{mM} \mathrm{NaCl}$, it is further exposed to EMS treatment under in vitro stress conditions. Further, control and EMS-treated $400 \mathrm{mM} \mathrm{NaCl}$ calluses of $A$. vulgaris were grown on MS media containing $4.44 \mu \mathrm{M}$ of $\mathrm{N}^{6}$-benzyladenine (BA) and $2.78 \mu \mathrm{M}$ of TDZ for shoot elongation (Figures 2a and 3a). Within two weeks of culture, shoot initiation was detected (Figures $2 b, c$ and $3 b, c)$. Further, the initiated shoots were successfully elongated in $1.44 \mu \mathrm{M} \mathrm{GA}_{3}$ containing MS medium (Figures $2 \mathrm{~d}$ and $3 \mathrm{~d}$ ). The well-elongated shoots from the control and EMS-treated calluses were further cultured in MS medium supplemented with IAA after 4 weeks of inoculation to produce roots. Among different concentrations of IAA, $5.70 \mu \mathrm{M}$ was found most successful for rooting (Figures 2e and 3e). Successfully rooted plantlets were transferred to standard laboratory conditions (Figures $2 \mathrm{f}$ and $3 \mathrm{f}$ ).

\subsection{Biochemical Analysis of Callus}

\subsubsection{Effect of Induced Mutation by $\mathrm{NaCl}$ and EMS on Photosynthetic Pigments}

The concentrations of chlorophyll and carotenoids in the callus of A. vulgaris were carried out, and total chlorophyll was expressed on unit fresh weight basis reduced by $25 \%$ following $400 \mathrm{~mm} \mathrm{NaCl}$ treatment, as compared to the control. On an FW basis, a similar trend in carotenoids content was observed. At high salt concentrations (100-400 mm), chlorophyll and carotenoids levels were reduced in (Table 1). The pigment contents were increased when stressed calluses were treated with $0.5 \%$ EMS (Table 1). 
Table 1. Mutagenic effect of sodium chloride $(\mathrm{NaCl})$ and ethyl methane sulphonate (EMS) on photosynthetic pigments of callus of A. vulgaris. The values reflect the mean standard deviation of three independent experiments. According to DMRT, means separated by different letters are significantly different from each other at $5 \%$ level of significance $(p \leq 0.05)$.

\begin{tabular}{|c|c|c|c|c|}
\hline Treatment & $\begin{array}{l}\text { Chlorophyll a } \\
\left(\mathrm{mg} \mathrm{g}^{-1} \text { FW) }\right.\end{array}$ & $\begin{array}{l}\text { Chlorophyll b } \\
\left(\mathrm{mg} \mathrm{g}^{-1} \text { FW) }\right.\end{array}$ & $\begin{array}{l}\text { Total Chlorophyll } \\
\quad\left(\mathrm{mg} \mathrm{g}^{-1} \mathrm{FW}\right)\end{array}$ & $\begin{array}{l}\text { Carotenoid } \\
\left(\mathrm{mg} \mathrm{g}^{-1} \mathrm{FW}\right)\end{array}$ \\
\hline \multicolumn{5}{|l|}{ Control } \\
\hline $0 \mathrm{mM}$ & $0.70 \pm 0.04 \mathrm{c}$ & $0.34 \pm 0.07 \mathrm{e}$ & $1.04 \pm 0.04 \mathrm{~b}$ & $0.58 \pm 0.008 \mathrm{~cd}$ \\
\hline \multicolumn{5}{|l|}{$\mathrm{NaCl}$ Stress } \\
\hline $100 \mathrm{mM}$ & $0.67 \pm 0.06 c$ & $0.30 \pm 0.04$ ef & $0.97 \pm 0.02 \mathrm{~cd}$ & $0.54 \pm 0.003 \mathrm{~d}$ \\
\hline $200 \mathrm{mM}$ & $0.61 \pm 0.03 \mathrm{~cd}$ & $0.28 \pm 0.01 \mathrm{ef}$ & $0.89 \pm 0.01 \mathrm{~d}$ & $0.49 \pm 0.001 \mathrm{de}$ \\
\hline $300 \mathrm{mM}$ & $0.57 \pm 0.04 \mathrm{~cd}$ & $0.24 \pm 0.02 \mathrm{f}$ & $0.81 \pm 0.07 \mathrm{de}$ & $0.48 \pm 0.009 \mathrm{de}$ \\
\hline $400 \mathrm{mM}$ & $0.54 \pm 0.02 \mathrm{~d}$ & $0.20 \pm 0.01 \mathrm{f}$ & $0.74 \pm 0.03 \mathrm{e}$ & $0.41 \pm 0.004 \mathrm{e}$ \\
\hline \multicolumn{5}{|c|}{$\mathrm{NaCl}+\mathrm{EMS}(0.5 \%)$} \\
\hline $100 \mathrm{mM}$ & $0.97 \pm 0.08 b$ & $0.57 \pm 0.01 \mathrm{~cd}$ & $1.54 \pm 0.06 \mathrm{a}$ & $0.79 \pm 0.004 b c$ \\
\hline $200 \mathrm{mM}$ & $0.93 \pm 0.05 b$ & $0.51 \pm 0.07 \mathrm{~d}$ & $1.44 \pm 0.06 \mathrm{a}$ & $0.79 \pm 0.007 \mathrm{bc}$ \\
\hline $300 \mathrm{mM}$ & $0.88 \pm 0.07 \mathrm{bc}$ & $0.51 \pm 0.04 \mathrm{~d}$ & $1.39 \pm 0.02 \mathrm{ab}$ & $0.73 \pm 0.003 b c$ \\
\hline $400 \mathrm{mM}$ & $0.84 \pm 0.03 \mathrm{bc}$ & $0.46 \pm 0.05 \mathrm{de}$ & $1.30 \pm 0.01 \mathrm{ab}$ & $0.69 \pm 0.008 c$ \\
\hline
\end{tabular}

\subsubsection{Effects on Carbohydrates (Total Sugar and Starch)}

Carbohydrate contents in the calluses were measured, and at higher concentrations of $\mathrm{NaCl}$, total sugar content increased gradually, and starch, on the other hand, decreased (Figure 4). Further, with mutagenic treatment with EMS, the contents of sugar and sucrose increased significantly (Figure 4). Moreover, the total sugar content was high at $400 \mathrm{mM}$ $\mathrm{NaCl}$, whereas the starch concentration was observed maximum at $100 \mathrm{mM} \mathrm{NaCl}$ under EMS treatment.

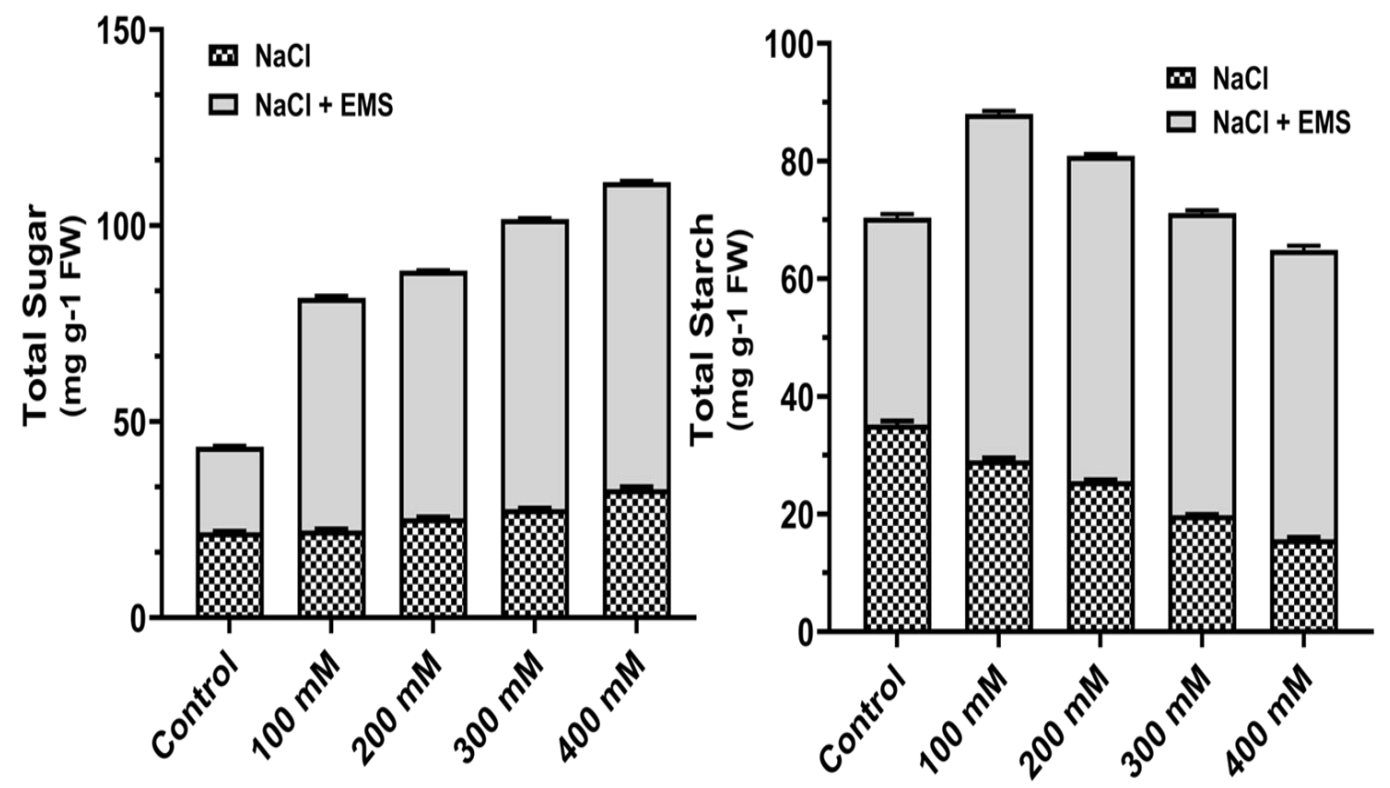

Figure 4. Mutagenic effect of sodium chloride $(\mathrm{NaCl})$ and ethyl methane sulphonate (EMS) on carbohydrates (total sugar and starch) contents of callus of $A$. vulgaris. The values reflect the mean standard deviation of three independent experiments. According to DMRT, means separated by different letters are significantly different from each other at $5 \%$ level of significance $(p \leq 0.05)$.

\subsubsection{Effects on the Free Amino Acid, Proline, and Total Phenol}

Salinity $(\mathrm{NaCl})$ stress decreases in the free amino acid pool, whereas the endogenous proline content increased under $\mathrm{NaCl}$ stress, with the maximum increase observed at $300 \mathrm{mM}$. The maximum increase in free amino acids was observed in stressed calluses treated with EMS (mutagenic agent) (Table 2). Under saline conditions, EMS-treated 
calluses showed a significant increase in total phenol over control, and $\mathrm{NaCl}$ stressed callus (Table 2).

Table 2. Mutagenic effect of sodium chloride $(\mathrm{NaCl})$ and ethyl methane sulphonate (EMS) on total free amino acids, proline, and total phenol contents of callus of A. vulgaris. The values reflect the mean standard deviation of three independent experiments. According to DMRT, means separated by different letters are significantly different from each other at $5 \%$ level of significance $(p \leq 0.05)$.

\begin{tabular}{|c|c|c|c|}
\hline Treatment & $\begin{array}{l}\text { Total Amino Acid } \\
\left(\mathrm{mg} \mathrm{g}^{-1} \mathrm{FW}\right)\end{array}$ & $\begin{array}{c}\text { Proline } \\
\left(\mathrm{mg} \mathrm{g}^{-1} \mathrm{FW}\right)\end{array}$ & $\begin{array}{l}\text { Total Phenol } \\
\left(\mathrm{mg} \mathrm{g}^{-1} \mathrm{FW}\right)\end{array}$ \\
\hline \multicolumn{4}{|l|}{ Control } \\
\hline $0 \mathrm{mM}$ & $29.8 \pm 0.3 \mathrm{c}$ & $43.0 \pm 0.2 \mathrm{~cd}$ & $27.3 \pm 0.3 c$ \\
\hline \multicolumn{4}{|l|}{$\mathrm{NaCl}$ Stress } \\
\hline $100 \mathrm{mM}$ & $25.8 \pm 0.6 c$ & $54.7 \pm 0.8 \mathrm{~b}$ & $25.6 \pm 0.6 c$ \\
\hline $200 \mathrm{mM}$ & $20.6 \pm 0.2 c$ & $59.2 \pm 0.9 \mathrm{~b}$ & $21.7 \pm 0.3 c$ \\
\hline $300 \mathrm{mM}$ & $15.8 \pm 0.4 \mathrm{~cd}$ & $69.4 \pm 0.1 \mathrm{a}$ & $19.4 \pm 0.2 \mathrm{~cd}$ \\
\hline $400 \mathrm{mM}$ & $10.7 \pm 0.6 \mathrm{~d}$ & $63.3 \pm 0.4 \mathrm{ab}$ & $14.1 \pm 0.4 \mathrm{~d}$ \\
\hline \multicolumn{4}{|c|}{$\mathrm{NaCl}+\mathrm{EMS}(0.5 \%)$} \\
\hline $100 \mathrm{mM}$ & $48.3 \pm 0.2 \mathrm{a}$ & $45.2 \pm 0.6 c$ & $51.6 \pm 0.2 \mathrm{a}$ \\
\hline $200 \mathrm{mM}$ & $43.2 \pm 0.8 \mathrm{ab}$ & $48.6 \pm 0.4 b c$ & $45.5 \pm 0.1 \mathrm{ab}$ \\
\hline $300 \mathrm{mM}$ & $39.2 \pm 0.4 b$ & $51.3 \pm 0.7 \mathrm{bc}$ & $40.0 \pm 0.1 b$ \\
\hline $400 \mathrm{mM}$ & $35.0 \pm 0.6 \mathrm{bc}$ & $44.4 \pm 0.5 c$ & $33.4 \pm 0.3 b c$ \\
\hline
\end{tabular}

\subsubsection{Effects on Antioxidant Enzyme Activities}

In the callus of $A$. vulgaris, the effect of mutations induced by $\mathrm{NaCl}$ and EMS on the total activity of three antioxidant enzymes, including Catalase (CAT), Peroxidase (POD), and Superoxide dismutase (SOD), was investigated and examined in the callus of $A$. vulgaris. As expected, the results showed a steady increase in the overall activity of POD and SOD from 100-400 mM NaCl, whereas CAT activity decreased (Figure 5). We recorded a further significant increase in CAT, POD, and SOD with mutagenic effects of EMS treatment. Furthermore, although POD and SOD activity peaked at $200 \mathrm{mM} \mathrm{NaCl}$, CAT activity was higher in $100 \mathrm{mM} \mathrm{NaCl}$ (Figure 5).
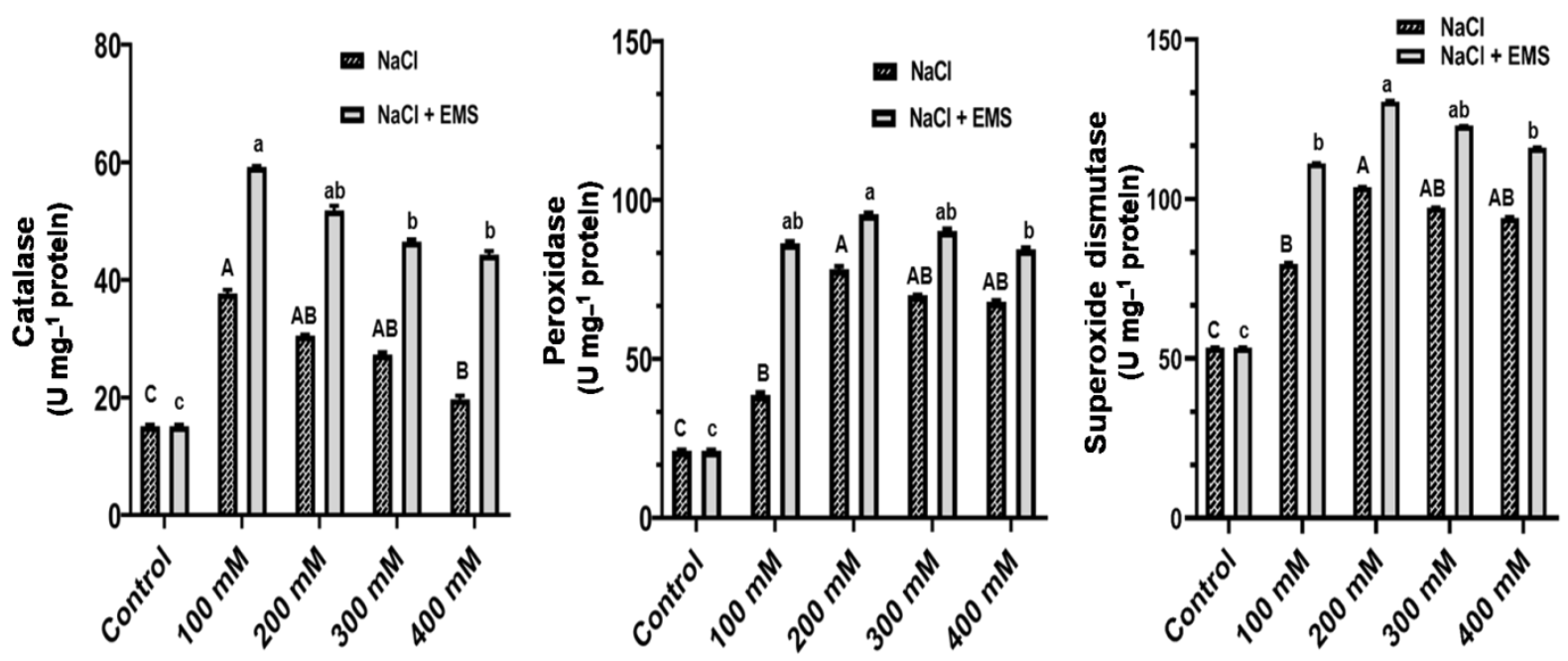

Figure 5. Antioxidant enzymes activities of (CAT, POD, and SOD) on $\mathrm{NaCl}$ and ethyl methane sulphonate induced mutation treated on calluses of $A$. vulgaris. The values reflect the mean $\pm \mathrm{SE}$ of three repeated experiments. Different letters correspond to a significant difference from each other at $(p \leq 0.05)$, according to DMRT. Uppercase for $\mathrm{NaCl}$ and lowercase for $(\mathrm{NaCl}+\mathrm{EMS})$. 


\section{Discussion}

One of the key environmental elements that affect the plants is salinity. Salt concentrations in the soil have a strong negative influence on all crop species growth and output. However, as many studies have shown, a crop's ability to endure and thrive in salt conditions varies widely among different species and varieties. In our present investigation, calluses developed from nodal stem explants were used with five different concentrations for assessing salt $(\mathrm{NaCl})$ tolerance in A. vulgaris. Salinity stress caused a significant effect on the growth and development of callus [32]. In our present study, $\mathrm{NaCl}$-stressed calluses were successfully regenerated with $0.5 \%$ EMS for $60 \mathrm{~min}$, exhibiting the most robust salt tolerance (Figure 2). It is possible that $60 \mathrm{~min}$ of exposure was the best length for $0.5 \%$ EMS treatment, which could stimulate the maximum frequency of mutagenesis for salt tolerance, were reported by [33]. However, salt tolerance in sugarcane mutants were developed from calluses mutated with EMS were previously observed [34].

In A. vulgaris chlorophyll and carotenoid levels were lowered by salinity but slightly increased with the mutagenic effects of $\mathrm{NaCl}$ and EMS combinations, a progressive decrease in chlorophyll a, chlorophyll b, total chlorophyll, and carotenoid was observed with $\mathrm{NaCl}$ alone (Table 1). The reduction in chlorophyll concentration under $\mathrm{NaCl}$ stress due to changes in the lipid-protein ratio of the pigment-protein complex activity was previously reported by [35]. Similar results were previous reported on decreased contents of chlorophyll and carotenoids by $(\mathrm{NaCl})$ salinity stress [36,37]. However, the EMS-treated callus showed a further increase in photosynthetic pigments, which directly implies the effectiveness of EMS on pigments of $A$. vulgaris.

In $A$. vulgaris, total sugar content increased by combining the mutagenic effects of salinity and EMS than $\mathrm{NaCl}$ alone (Figure 4). Our results are supported by previous reports that salt stress increases, glucose, sucrose, and fructans in many plants [38]. The activity of sucrose phosphate synthase increases as the concentration of reducing and nonreducing sugars rises in salinity, whereas starch phosphorylase activity decreases [39]. The mutagenic effects of EMS on NaCl-stressed calluses showed a further increase in contents of carbohydrates. We found a further increase in total amino acid when $\mathrm{NaCl}$ stressed the callus of $A$. vulgaris treated with EMS. Increased content of proline and total phenol was observed under salinity stress in A. vulgaris (Table 2).

Plants under stress, meanwhile, develop defensive systems to counteract the harmful consequences of oxidative stress. One of the most common defense responses to abiotic stressors is ROS scavenging [40]. The primary enzymatic ROS scavenging activities include catalase (CAT), superoxide dismutase (SOD), and peroxidase (POD). SOD may catalyse the dismutation of superoxide radicals to generate $\mathrm{O}_{2}$ and $\mathrm{H}_{2} \mathrm{O}_{2}$, the produced $\mathrm{H}_{2} \mathrm{O}_{2}$ eliminated by POD and CAT in Pisum sativum and Brassica chinensis reported by [41].

The results of this investigation revealed that all three antioxidant enzymes were active in the callus of $A$. vulgaris. Under salinity $(\mathrm{NaCl})$ stress situation, anti-oxidative stress ability was linked. The anti-oxidative response varies based on the species, the plant's development and metabolic condition, and the length and intensity of the stress. The activity of SOD and POD increased under $\mathrm{NaCl}$ stress. Similarly, catalase activity was found lower than SOD and POD (Figure 5). Interestingly, the high SOD activity coincided with changes in the specific activities of POD assay. However, catalase activities were suppressed under salinity $(\mathrm{NaCl})$ stress. Additionally, the combination of mutagenic effect of EMS and $\mathrm{NaCl}$ treatment showed a significant rise in the activities of CAT, POD, and SOD over control and $\mathrm{NaCl}$ stress (Figure 5).

\section{Conclusions}

According to the findings of this study, it can be stated that salinity had an impact on A. vulgaris growth and regeneration. Treatment with EMS had a mutagenesis impact, which reduced the toxic effects of $\mathrm{NaCl}$ stress and resulted in increased growth and biochemical activities. The improved salt tolerance of mutants implies that $A$. vulgaris mutagenesis with EMS is significant. This approach could be effective for mutation breeding and the creation 
of salt-tolerant medicinal plants for successful cultivation, thereby providing raw material to pharmaceutical companies and local medicinal purposes.

Author Contributions: Conceptualization, methodology, software, formal analysis, investigation, writing — original draft preparation S.P.K.; validation, visualization, S.P.K. and B.R.K.; supervision, project administration, funding acquisition, B.R.K. All authors have read and agreed to the published version of the manuscript.

Funding: This research received no external funding.

Institutional Review Board Statement: The study was conducted according to the guidelines of the Declaration of Helsinki, and approvrd by the Institutional Review Board.

Informed Consent Statement: Not applicable.

Data Availability Statement: Not applicable.

Conflicts of Interest: There are no conflicts of interest.

\section{References}

1. Malik, S.; De Mesquita, L.S.S.; Silva, C.R.; De Mesquita, J.W.C.; De Sá Rocha, E.; Bose, J.; Abiri, R.; Figueiredo, P.D.M.S.; Costa, L.M. Chemical Profile and Biological Activities of Essential Oil from Artemisia Vulgaris L. Cultivated in Brazil. Pharmaceuticals 2019, 12, 49. [CrossRef]

2. Nithya Devi, V.; Pradeep Kumar, S. Evaluation of the Antibacterial Potential, Preliminary Phytochemical Screening of Medicinal Plant against Plant Pathogen. Res. J. Phytochem. 2014, 8, 92-101.

3. Pandey, N.; Meena, R.P.; Rai, S.K.; Pandey-Rai, S. In Vitro Generation of High Artemisinin Yielding Salt Tolerant Somaclonal Variant and Development of SCAR Marker in Artemisia Annua L. Plant Cell Tissue Organ Cult. 2016, 127, 301-314. [CrossRef]

4. Machado, R.M.A.; Serralheiro, R.P. Soil Salinity: Effect on Vegetable Crop Growth. Management Practices to Prevent and Mitigate Soil Salinization. Horticulturae 2017, 3, 30. [CrossRef]

5. Rao, N.; Lawson, E.T.; Raditloaneng, W.N.; Solomon, D.; Angula, M.N. Gendered Vulnerabilities to Climate Change: Insights from the Semi-Arid Regions of Africa and Asia. Clim. Dev. 2019, 11, 14-26. [CrossRef]

6. Shahid, M.A.; Sarkhosh, A.; Khan, N.; Balal, R.M.; Ali, S.; Rossi, L.; Gómez, C.; Mattson, N.; Nasim, W.; Garcia-Sanchez, F. Insights into the Physiological and Biochemical Impacts of Salt Stress on Plant Growth and Development. Agronomy 2020, 10, 938. [CrossRef]

7. AbdElgawad, H.; Zinta, G.; Hegab, M.M.; Pandey, R.; Asard, H.; Abuelsoud, W. High Salinity Induces Different Oxidative Stress and Antioxidant Responses in Maize Seedlings Organs. Front. Plant Sci. 2016, 7, 276. [CrossRef] [PubMed]

8. Lang, D.; Yu, X.; Jia, X.; Li, Z.; Zhang, X. Methyl Jasmonate Improves Metabolism and Growth of NaCl-Stressed Glycyrrhiza Uralensis Seedlings. Sci. Hortic. 2020, 266, 109287. [CrossRef]

9. Sies, H.; Jones, D.P. Reactive Oxygen Species (ROS) as Pleiotropic Physiological Signalling Agents. Nat. Rev. Mol. Cell Biol. 2020, 21,363-383. [CrossRef]

10. Arisha, M.H.; Shah, S.N.M.; Gong, Z.H.; Jing, H.; Li, C.; Zhang, H.X. Ethyl Methane Sulfonate Induced Mutations in M2 Generation and Physiological Variations in M1 Generation of Peppers (Capsicum Annuum L.). Front. Plant Sci. 2015, 6, 399. [CrossRef]

11. Waugh, R.; Leader, D.J.; McCallum, N.; Caldwell, D. Harvesting the Potential of Induced Biological Diversity. Trends Plant Sci. 2006, 11, 71-79. [CrossRef]

12. Bolívar-González, A.; Valdez-Melara, M.; Gatica-Arias, A. Responses of Arabica Coffee (Coffea Arabica L. Var. Catuaí) Cell Suspensions to Chemically Induced Mutagenesis and Salinity Stress under in Vitro Culture Conditions. Vitr. Cell. Dev. Biol. Plant 2018, 54, 576-589. [CrossRef]

13. Lethin, J.; Shakil, S.S.M.; Hassan, S.; Sirijovski, N.; Töpel, M.; Olsson, O.; Aronsson, H. Development and Characterization of an EMS-Mutagenized Wheat Population and Identification of Salt-Tolerant Wheat Lines. BMC Plant Biol. 2020, 20, 18. [CrossRef] [PubMed]

14. Singh, A.K.; Chaurasia, S.; Kumar, S.; Singh, R.; Kumari, J.; Yadav, M.C.; Singh, N.; Gaba, S.; Jacob, S.R. Identification, Analysis and Development of Salt Responsive Candidate Gene Based SSR Markers in Wheat. BMC Plant Biol. 2018, 18, 249. [CrossRef]

15. Hasanuzzaman, M.; Bhuyan, M.H.M.B.; Zulfiqar, F.; Raza, A.; Mohsin, S.M.; Al Mahmud, J.; Fujita, M.; Fotopoulos, V. Reactive Oxygen Species and Antioxidant Defense in Plants under Abiotic Stress: Revisiting the Crucial Role of a Universal Defense Regulator. Antioxidants 2020, 9, 681. [CrossRef] [PubMed]

16. Kiełkowska, A.; Grzebelus, E.; Lis-Krzyścin, A.; Maćkowska, K. Application of the Salt Stress to the Protoplast Cultures of the Carrot (Daucus Carota L.) and Evaluation of the Response of Regenerants to Soil Salinity. Plant Cell Tissue Organ Cult. 2019, 137, 379-395. [CrossRef] 
17. Khan, N.; Bano, A.; Rahman, M.A.; Guo, J.; Kang, Z.; Babar, M.A. Comparative Physiological and Metabolic Analysis Reveals a Complex Mechanism Involved in Drought Tolerance in Chickpea (Cicer Arietinum L.) Induced by PGPR and PGRs. Sci. Rep. 2019, 9, 2097. [CrossRef]

18. Li, L.; Peng, Z.; Mao, X.; Wang, J.; Li, C.; Chang, X.; Jing, R. Genetic Insights into Natural Variation Underlying Salt Tolerance in Wheat. J. Exp. Bot. 2021, 72, 1135-1150. [CrossRef] [PubMed]

19. Mangu, V.R.; Ratnasekera, D.; Yabes, J.C.; Wing, R.A.; Baisakh, N. Functional Screening of Genes from a Halophyte Wild Rice Relative Porteresia Coarctata in Arabidopsis Model Identifies Candidate Genes Involved in Salt Tolerance. Curr. Plant Biol. 2019, 18, 100107. [CrossRef]

20. Kumar, S.P.; Kumari, B.D.R. Effect of Amino Acids and Growth Regulators on Indirect Organogenesis in Artemisia Vulgaris L. Asian J. Biotechnol. 2009, 2, 37-45. [CrossRef]

21. Murashige, T.; Skoog, F. A Revised Medium for Rapid Growth and Bio Assays with Tobacco Tissue Cultures. Physiol. Plant. 1962, 15, 473-497. [CrossRef]

22. Pradeep Kumar, S.; Ranjitha Kumari, B.D. Indirect Somatic Embryogenesis from Transgenic Immature Leaf of Safflower Carthamus Tinctorius (Mohler, Roth, Schmidt \& Boudreaux, 1967) (Asterales: Asteraceae). Braz. J. Biol. Sci. 2017, 4, 247-258. [CrossRef]

23. Chow, P.S.; Landhäusser, S.M. A Method for Routine Measurements of Total Sugar and Starch Content in Woody Plant Tissues. Tree Physiol. 2004, 24, 1129-1136. [CrossRef] [PubMed]

24. Landhäusser, S.M.; Chow, P.S.; Turin Dickman, L.; Furze, M.E.; Kuhlman, I.; Schmid, S.; Wiesenbauer, J.; Wild, B.; Gleixner, G.; Hartmann, H.; et al. Standardized Protocols and Procedures Can Precisely and Accurately Quantify Non-Structural Carbohydrates. Tree Physiol. 2018, 38, 1764-1778. [CrossRef] [PubMed]

25. Parida, A.K.; Dagaonkar, V.S.; Phalak, M.S.; Umalkar, G.V.; Aurangabadkar, L.P. Alterations in Photosynthetic Pigments, Protein and Osmotic Components in Cotton Genotypes Subjected to Short-Term Drought Stress Followed by Recovery. Plant Biotechnol. Rep. 2007, 1, 37-48. [CrossRef]

26. Akitha Devi, M.K.; Giridhar, P. Variations in Physiological Response, Lipid Peroxidation, Antioxidant Enzyme Activities, Proline and Isoflavones Content in Soybean Varieties Subjected to Drought Stress. Proc. Natl. Acad. Sci. India Sect. B Biol. Sci. 2015, 85, 35-44. [CrossRef]

27. Maisuthisakul, P.; Suttajit, M.; Pongsawatmanit, R. Assessment of Phenolic Content and Free Radical-Scavenging Capacity of Some Thai Indigenous Plants. Food Chem. 2007, 100, 1409-1418. [CrossRef]

28. Pradeep Kumar, S.; Ranjitha Kumari, B.D. Antioxidant and in Situ Chitinase Gel Activity in Safflower (Carthamus Tinctorius L.). World Appl. Sci. J. 2013, 24, 46-52. [CrossRef]

29. Hadwan, M.H. Simple Spectrophotometric Assay for Measuring Catalase Activity in Biological Tissues. BMC Biochem. 2018, 19, 7. [CrossRef]

30. Macková, M.; Ferri, E.N.; Demnerová, K.; Macek, T. Quantitative Chemiluminiscent Detection of Plant Peroxidases Using a Commercial Kit Originally Designed for Blotting Assays. Chem. List. 2001, 95, 130-132.

31. Lee, E.H.; Bennett, J.H. Superoxide dismutase: A possible protective enzyme against ozone injury in snap beans (Phaseolus vulgaris L.). Plant Physiol. 1982, 69, 1444-1449. [CrossRef]

32. Muchate, N.S.; Rajurkar, N.S.; Suprasanna, P.; Nikam, T.D. NaCl Induced Salt Adaptive Changes and Enhanced Accumulation of 20-Hydroxyecdysone in the In Vitro Shoot Cultures of Spinacia Oleracea (L.). Sci. Rep. 2019, 9, 12522. [CrossRef] [PubMed]

33. Khalil, F.; Naiyan, X.; Tayyab, M.; Pinghua, C. Screening of Ems-Induced Drought-Tolerant Sugarcane Mutants Employing Physiological, Molecular and Enzymatic Approaches. Agronomy 2018, 8, 226. [CrossRef]

34. Masoabi, M.; Lloyd, J.; Kossmann, J.; Van der Vyver, C. Ethyl Methanesulfonate Mutagenesis and In Vitro Polyethylene Glycol Selection for Drought Tolerance in Sugarcane (Saccharum spp.). Sugar Tech 2018, 20, 50-59. [CrossRef]

35. Khoshbakht, D.; Asghari, M.R.; Haghighi, M. Effects of Foliar Applications of Nitric Oxide and Spermidine on Chlorophyll Fluorescence, Photosynthesis and Antioxidant Enzyme Activities of Citrus Seedlings under Salinity Stress. Photosynthetica 2018, 56, 1313-1325. [CrossRef]

36. Rangani, J.; Parida, A.K.; Panda, A.; Kumari, A. Coordinated Changes in Antioxidative Enzymes Protect the Photosynthetic Machinery from Salinity Induced Oxidative Damage and Confer Salt Tolerance in an Extreme Halophyte Salvadora Persica L. Front. Plant Sci. 2016, 7, 50. [CrossRef] [PubMed]

37. Rahneshan, Z.; Nasibi, F.; Moghadam, A.A. Effects of Salinity Stress on Some Growth, Physiological, Biochemical Parameters and Nutrients in Two Pistachio (Pistacia Vera L.) Rootstocks. J. Plant Interact. 2018, 13, 73-82. [CrossRef]

38. Ainsworth, E.A.; Gillespie, K.M. Estimation of Total Phenolic Content and Other Oxidation Substrates in Plant Tissues Using Folin-Ciocalteu Reagent. Nat. Protoc. 2007, 2, 875-877. [CrossRef]

39. Lu, N.; Luo, Z.; Ke, Y.; Dai, L.; Duan, H.; Hou, R.; Cui, B.; Dou, S.; Zhang, Y.; Sun, Y.; et al. Growth, Physiological, Biochemical, and Ionic Responses of Morus Alba L. Seedlings to Various Salinity Levels. Forests 2017, 8, 488. [CrossRef]

40. Wang, R.; Chen, S.; Zhou, X.; Shen, X.; Deng, L.; Zhu, H.; Shao, J.; Shi, Y.; Dai, S.; Fritz, E.; et al. Ionic Homeostasis and Reactive Oxygen Species Control in Leaves and Xylem Sap of Two Poplars Subjected to NaCl Stress. Tree Physiol. 2008, $28,947-957$. [CrossRef]

41. Liu, N.; Lin, Z.; Guan, L.; Gaughan, G.; Lin, G. Antioxidant Enzymes Regulate Reactive Oxygen Species during Pod Elongation in Pisum Sativum and Brassica Chinensis. PLoS ONE 2014, 9, e87588. [CrossRef] [PubMed] 